\title{
RISK ASSESSMENT FOR PROLONGED RUPTURE TO DELIVERY INTERVAL IN CASE OF PREMATURE BREAKING OF MEMBRANES AT 34-36 WEEKS' GESTATION
}

\author{
Shakhbazova V. A. ${ }^{1}$, Autleva S. R. ${ }^{2}$ \\ ${ }^{1}$ Kuban State Medical University, Krasnodar, Russian Federation \\ 2 JSC Kuban Medical Center, Krasnodar, Russian Federation
}

\section{ОЦЕНКА РИСКОВ ААИТЕАЬНОГО БЕЗВОАНОГО ПРОМЕЖУТКА ПРИ ПРЕЖАЕВРЕМЕННОМ РАЗРЫВЕ ПАОАНЫХ ОБОАОЧЕК В СРОКЕ БЕРЕМЕННОСТИ 34-36 HЕАЕАЬ}

\author{
В. А. Шахбазова', С. Р. Аутлева \\ 1'Кубанский госуАарственный меАицинский университет, КрасноАар, \\ Российская ФеАерация \\ 2 ООО «Кубанский МеАицинский центрп, КрасноАар, Российская ФеАерация
}

Premature rupture of membranes (PROM) especially at a gestational age of 34-36 weeks is a relevant issue in Obstetrics nowadays. The study included 100 pregnant women (residents of Krasnodar Region) at 34-36 weeks' gestation. There were the main risk factors identified for prolonged rupture to delivery interval at PROM in case of 34-36 pregnancy term, which may be 109.1 12.63 hours prior to spontaneous labor development. There was also the role of cervical ectopia found out in relation to PROM at gestational age under 21 weeks.

Key words: premature rupture of membranes, cervical ectopia, cervicometry, vaginal environment pH-metry

Преждевременный разрыв плодных оболочек (ПРПО), особенно в гестационном сроке 34-36 недель, является актуальным вопросом современного акушерства. Обследовано 100 женщин Краснодарского края в сроке беременности 34-36 недель. Определены основные факторы риска длительного безводного периода при ПРПО в сроке беременности 34-36 недель, который

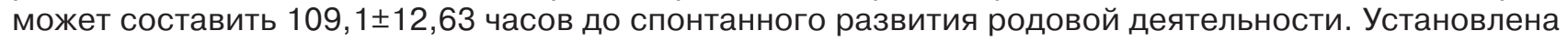
роль эктопии шейки матки в ПРПО в сроке беременности до 21 недели.

Ключевые слова: преждевременный разрыв плодных оболочек, эктопия шейки матки, цервикометрия, ph-метрия вагинальной среды

P remature rupture of membranes (PROM) is a complication of pregnancy course characterized by disturbed integrity of fetal membranes and amniorrhea prior to the onset of labor regardless of the gestational age 1, 9,14. The major risk factors for PROM are not unknown - inflammation of the uterine cervix and vagina, multifetal gestation, burdened history, urinary tract infection, uterine pathology, obesity, diabetes mellitus. However, in case of incomplete pregnancy PROM may take place even without the known risk factors in place $[1,8]$. The most common pathogenic mechanism for PROM at incomplete pregnancy is an infection in the lower pole of the fetal bladder $[16,19]$.

Despite numerous reviews offered by Russian and foreign experts $[1,2,6,7,13,14]$ there is still lack of understanding as to why, in case of PROM at 34-36 weeks' gestation, the regular contractile activity of the uterus fails to develop sometimes and the rupture to delivery interval may take a prolonged course thus posing a threat to the health of mother and fetus.

The purpose of this present study was to identify the factors contributing to the delay of spontaneous labor after premature rupture of membranes in women at 34-36 weeks' gestation.

Material and Methods. 100 pregnant women (residents of Krasnodar Region) with PROM underwent examination at the Department of Obstetrics, Gynecology and Perinatology of Kuban State Medical University (Regional Perinatal Center of Krasnodar; Perinatal Center of Krasnodar at Hospital № 2). The 100 women suffered from 
PROM at 34-36 weeks of gestation, and no regular uterine activity occurred within the next 24 hours (main group). The comparison group consisted of 100 women who developed spontaneous preterm delivery (gestation - 34-36 weeks) at PROM. The gestational age was $35.6 \pm 1.12$ weeks. The mean age of the patients was $27.4 \pm 2.75$ yrs.

The performed measures included data analysis from the medical cards of the obstetric patients and from the labor and delivery medical records; there was also identification done regarding prognostically significant risk factors for PROM. The ultrasound study (US) of the cervix was performed with expert-class machines Volusson-730, PHILIPS HD11 (intravaginal sensor, frequency $7.5-12.0 \mathrm{MHz}$; transabdominal sensor, frequency $3.5 \mathrm{MHz}$ ). PROM was diagnosed based on a visual assessment, the cough test, the Amnisure test system, and the data obtained through ultrasound scanning. The vaginal acidity was screened with the Citolab vaginal $\mathrm{pH}$ test. For the identification of the pathogenic microflora (protozoans, viruses, bacteria), colonizing the urogenital tract, as well as for quantifying the total bacterial mass and lactobacilli, major anaerobic microorganisms, mycoplasmas and yeasts important for developing dysbiotic processes of varying severity, the real-time PCR was employed and Femoflor ${ }^{\circledR}$ Screen and Femoflor ${ }^{\circledR}-16$.

The statistical analysis of the study outcomes was done with the statistics packages SPSS v15.0, Microsoft Excel 2007. There were calculations done concerning the numerical characteristics of an ordered sample ( $\mathrm{M}$ - mean value, $\mathrm{m}$ - average error of the arithmetic mean); the significance of various samples was determined by $p$ (the Student's t-test). For $n=100, p=0.05$ at the critical value of $t=1.984 ; p=0.01$ at $t=2.626 ; p=0.001$ at $\mathrm{t}=3.390$. The odds ratio $(\mathrm{OR})$ was calculated in view of the $95 \%$ confidence interval $(\mathrm{Cl})$ accepted as a probability estimate of the outcome under investigation.

Results and Discussion. In contrast to the comparison group, the women in the main group significantly more often developed cervical ectopia (CE) $(p<0.001)$, had preterm delivery in the history $(p<0.01)$, and were aged over $35(p<0.01)$.

In cases of CE in 58(88\%) out of 66 women of the main group and $12(55 \%)$ out of the 22 women in the comparison group, the first and the second trimesters of pregnancy were aggravated with incipient abortion the leading clinical manifestation of which was bloody issue from the vagina of varying intensity. Colposcopy revealed signs of an acute cervicitis: vascular congestion, redness and swelling of the mucous layer, mainly in the damaged epithelium, multiple petechial hemorrhages, and contact bleeding.

The bloody issue from the reproductive tract in the first trimester, according to US in 34 (34\%) women of the main group and in 31 (31\%) women of the comparison group ( $p>0.05)$ was due to partial non-progressive chorion detachment.
US cervicometry performed in the II-III trimesters showed that in $100 \%$ of the cases of the comparison group the cervical length was less than 25 $\mathrm{mm}$ at 24-31 weeks of the gestational age, while in $59(59 \%)$ women of the main group and in 42 (42\%) cases of the comparison group, the width of the cervical canal was $1 \mathrm{~cm}$ or more at the gestational age of under 21 weeks.

US showed the women with CE had dilatation of the cervical canal up to $0.83 \pm 0.02 \mathrm{~cm}$ in the I-II trimesters, which, in case of under 21 weeks of pregnancy, we tend to consider a condition for infection of the lower pole of fetal bladder and PROM.

The clinical signs of endocervicitis were detected more often in women of the main group (Table 1). Note to be made that in women with PROM at 34-36 weeks' gestation a long rupture to delivery interval was associated with the cervical ectopia and concomitant endo- or exocervicitis.

\begin{tabular}{|c|c|c|c|c|c|}
\hline \multirow{3}{*}{ Index } & \multirow{3}{*}{$\begin{array}{c}\text { Odds } \\
\text { ratio } \\
(\mathrm{OR}, \\
95 \% \mathrm{CI})\end{array}$} & \multicolumn{4}{|c|}{ Groups } \\
\hline & & \multicolumn{2}{|c|}{$\begin{array}{l}\text { Main group } \\
(n=100)\end{array}$} & \multicolumn{2}{|c|}{$\begin{array}{c}\text { Comparison } \\
\text { group } \\
(n=100)\end{array}$} \\
\hline & & $\begin{array}{l}\text { Abs. } \\
\text { num- } \\
\text { ber }\end{array}$ & $\%$ & $\begin{array}{c}\text { Abs. } \\
\text { number }\end{array}$ & $\%$ \\
\hline $\begin{array}{l}\text { Number of } \\
\text { women with } \\
\text { endocervicitis }\end{array}$ & $\begin{array}{c}2.667 \\
{[1.336-} \\
5.323]\end{array}$ & 32 & $32 *$ & 15 & 15 \\
\hline $\begin{array}{l}\text { Number of } \\
\text { women with } \\
\text { cervical ecto- } \\
\text { pia (CE) }\end{array}$ & $\begin{array}{c}6.888 \\
{[3.671-} \\
12.904]\end{array}$ & 66 & $66 * *$ & 22 & 22 \\
\hline $\begin{array}{l}\text { Number of } \\
\text { women with } \\
\text { endocervicitis } \\
\text { and CE }\end{array}$ & $\begin{array}{c}8.877 \\
{[2.975-} \\
26.489]\end{array}$ & 27 & $27 * *$ & 4 & 4 \\
\hline \begin{tabular}{|l|} 
Number of \\
women with \\
exocervicitis
\end{tabular} & $\begin{array}{c}6.291 \\
{[3.296-} \\
12.009] \\
\end{array}$ & 58 & $58 *$ & 18 & 18 \\
\hline $\begin{array}{l}\text { Number of } \\
\text { women with } \\
\text { exocervicitis } \\
\text { and CE } \\
\end{array}$ & $\begin{array}{c}6.652 \\
{[3.386-} \\
13.068]\end{array}$ & 54 & $54 * *$ & 15 & 15 \\
\hline $\begin{array}{l}\text { Exocervicitis } \\
\text { and CE against } \\
\text { cylindrical } \\
\text { epithelium } \\
\end{array}$ & $\begin{array}{c}5.222 \\
{[2.037-} \\
13.386]\end{array}$ & 25 & $25 * *$ & 6 & 6 \\
\hline $\begin{array}{l}\text { Exocervicitis } \\
\text { and CE against } \\
\text { stratified squa- } \\
\text { mous epithe- } \\
\text { lium }\end{array}$ & $\begin{array}{c}4.130 \\
{[1.838-} \\
9.281]\end{array}$ & 29 & $29 * *$ & 9 & 9 \\
\hline
\end{tabular}

Note: ${ }^{*}-\mathrm{p}<0.001 ;{ }^{* \star}-\mathrm{p}<0.001-$ matching the main group values with those of the comparison group.

Indeed, according to the data reported by Russian researchers, the frequency of inflammatory changes of the cervix goes up 4-fold when there is cylindrical epithelium in the cervix (based on colposcopy) by the III trimester, compared with earlier periods of pregnancy. Yet, despite changes in the 
cervix in $64.3 \%$ of the pregnant women (ectopias or polyps), the frequency of the pregnancy complications was $20 \%$ and didn't exceed those in women with normal cervices. The vast majority of women (87-90\%) had delivery that was uneventful and did not depend on the cervix status [lintra-group comparison of vaginal $\mathrm{pH}$-metry (Table 2) showed that women with CE had their vaginal ph significantly higher than women with no CE: the main group $6.65 \pm 0.03$ vs. $6.32 \pm 0.05(p<0.001)$, the comparison group $-4.85 \pm 0.01$ vs. $4.16 \pm 0.02(p<0.001)$ (Table 1). This suggests that a $\mathrm{pH}$ increase at the gestational age of 34-36 weeks, being an indicator of dysbiotic processes in the vagina, is a risk factor for PROM yet is not a predictor of regular labor in the next 24 hours.

Table 2

Specific issues in vaginal $\mathrm{pH}$-metry in pregnant women of compared groups

\begin{tabular}{|l|c|c|}
\hline \multirow{2}{*}{\multicolumn{1}{|c|}{ Index }} & \multicolumn{2}{|c|}{ Groups } \\
\cline { 2 - 3 } & $\begin{array}{c}\text { Main group } \\
(n=100)\end{array}$ & $\begin{array}{c}\text { Comparison group } \\
(n=100)\end{array}$ \\
\hline $\begin{array}{l}\text { Vaginal } \mathrm{pH} \text {-metry } \\
\text { without CE }\end{array}$ & $\begin{array}{c}(\mathrm{n}=44) \\
(\mathrm{n}=88)\end{array}$ \\
\hline $\begin{array}{l}\text { Vaginal } \mathrm{pH} \text {-metry } \\
\text { with CE }\end{array}$ & $(\mathrm{n}=66)$ & $4.16 \pm 0.02$ \\
\hline
\end{tabular}

Note: ${ }^{* *}-p<0.001-$ matching the main group values with those of the control group.

Testing of vaginal $\mathrm{pH}$ levels has been recognized as a unique method for objective evaluation of the vaginal acid-base balance, clinical interpretation of vaginal microecology, and differential diagnosis of bacterial vaginosis [Some researchers argue that the bacterial microflora of the amniotic fluid always coincides with the micro-organisms colonizing the cervical canal [4]. Therefore, the vaginal contents $\mathrm{pH}$-metry may be used to identify female risk groups for PROM.

When detecting the infectious risk factor for PROM we took into view that normal amniotic fluid is to be sterile, and bacteria are found in the amniotic fluid in less than $1 \%$ of women with full-term pregnancy [13]. In case of preterm delivery (PD) the amniotic fluid can be described as having higher levels of microbial colonization and inflammatory cytokines than the amniotic fluid in the same gestational age or during labor at full-term pregnancy [13]. The presence of intrauterine infection even in the absence of clinical symptoms is associated with an increased risk of PD [13]. Around $40 \%$ of preterm delivery is associated with intrauterine infection and the resulting inflammation $[13,17]$.

Foreign literature offers the term microbial invasion of the amniotic cavity (MIAC). In case of threatened PD and intact fetal membranes, the MIAC rate is $12.8 \%$, while in case of PROM and incomplete pregnancy it is $32.4 \%$, and in case of PROM and the onset of the regular labor at incomplete pregnancy the value is $75 \%[13,18,19]$.

Some researchers argue that the bacterial microflora of the amniotic fluid always coincides with the micro-organisms colonizing the cervical canal [10]. This current research produced quite the opposite results - in all cases, both in the main and the comparison groups the microbial compositions of the cervical discharge and the amniotic fluid were different. Thus, the study of the microbial spectrum of the cervical canal discharge before PROM and the amniotic fluid and uterus in the early postpartum period revealed (Table 3 ) that prevailing in the cervical canal were Enterococcus faecialis, Escherichia coli, Staphylococcus epidermidis, Ureaplasma urealyticum, while Enterococcus faecialis, Escherichia coli, Staphylococcus epidermidis were also detected in the amniotic fluid. Most women were found out to have Enterococcus faecialis, Escherichia coli in the cavity of the uterus in the early postpartum period. Besides, an examination of the microbial flora in the cervical canal showed Ureaplasma urealyticum in the clinically significant titer, yet lower in frequency if compared to Enterococcus faecialis, Escherichia coli. Females of the main group had Enterococcus faecialis and Escherichia coli found in them significantly more often in the cervical canal prior to amniorrhea $(p<0.05)$ and in the cavity of the uterus in the postpartum period $(p<0.001)$.

Table 3

Microorganisms isolated from genital tract in women of compared groups

\begin{tabular}{|c|c|c|c|c|}
\hline \multirow{3}{*}{ Index } & \multicolumn{4}{|c|}{ Groups } \\
\hline & \multicolumn{2}{|c|}{$\begin{array}{l}\text { Main group } \\
(n=100)\end{array}$} & \multicolumn{2}{|c|}{\begin{tabular}{|c|c|} 
Comparison \\
group \\
$(\mathrm{n}=100)$
\end{tabular}} \\
\hline & $\begin{array}{l}\text { Abs. } \\
\text { num- } \\
\text { ber }\end{array}$ & $\%$ & $\begin{array}{c}\text { Abs. } \\
\text { num- } \\
\text { ber }\end{array}$ & $\%$ \\
\hline \multicolumn{5}{|c|}{ Cervical canal } \\
\hline Ureaplasma urealyticum & 20 & 20 & 14 & 14 \\
\hline Chlamydia & 0 & 0 & 2 & 2 \\
\hline Gardnerella vaginalis & 21 & 21 & 23 & 23 \\
\hline Enterococcus faecialis & 91 & $91 *$ & 79 & 79 \\
\hline Escherichia coli & 81 & $81 *$ & 69 & 69 \\
\hline $\begin{array}{l}\text { Staphylococcus } \\
\text { epidermidis }\end{array}$ & 52 & 52 & 64 & 64 \\
\hline Candida albicans & 11 & 11 & 14 & 14 \\
\hline Candida brucei & 2 & 2 & 0 & 0 \\
\hline \multicolumn{5}{|c|}{ Amniotic fluid } \\
\hline Enterococcus faecialis & 13 & 13 & 13 & 13 \\
\hline Escherichia coli & 10 & 10 & 0 & 0 \\
\hline $\begin{array}{l}\text { Staphylococcus } \\
\text { epidermidis }\end{array}$ & 20 & 20 & 0 & 0 \\
\hline \multicolumn{5}{|c|}{ The uterine cavity } \\
\hline Ureaplasma urealyticum & 32 & 32 & 22 & 22 \\
\hline Chlamydia trachomatis & 0 & 0 & 2 & 2 \\
\hline Enterococcus faecialis & 100 & $100 * *$ & 28 & 28 \\
\hline Escherichia coli & 79 & $79 * *$ & 25 & 25 \\
\hline Kocuria rosea & 3 & 3 & 0 & 0 \\
\hline
\end{tabular}

Note: ${ }^{*}-p<0.05 ;{ }^{* *}-p<0.001-$ matching the main group values with those of the control (comparison) group. 
Scientific literature offers numerous reviews focusing on PROM. Stress is made there that appropriate amnion with enough amniotic fluid protects the fetus against ascending infection. Along with increasing gestational age there is also a decrease in collagen synthesis and in the synthesis of collagen-stabilizing enzymes, increased collagen degradation by matrix metalloproteinases, which enhances the ability of the collagen to get dissolved and reduces the resistance of the amnion membrane $[1,7]$. As a result of the amnion infection there is risk of impairment in its integrity and premature discharge of amniotic fluid [10].

Hydramnion was identified in $20(20 \%)(p<0.01)$ of the women in the main group (AFI $=20.5 \pm 0.30)$, and in $6(6 \%)$ women of the comparison group (AFI 18.2 \pm 0.22 ). Whether PROM was an effect of amniotic tissue hyperextension, infection of the lower pole of the fetal membranes, or due to a combination of the two factors it was impossible to detect within this present study.

If, prior to 34 weeks of pregnancy the recommended tactics is (active) wait-and-seeing then after that term the tactics is active as there is an increased risk of infection and compression of the umbilical cord [9]. However, in case of sufficient amniotic fluid, biological immaturity of the cervix, absence of clinical signs of intrauterine infection, and the woman's refusal to get birth preinduction, the tactics for active pregnancy management is to be selected on an individual basis.

This study offers an evaluation of the biological maturity of the uterine cervix, which was $6.2 \pm 0.5$ points $(p<0.01)$ in the main group and $7.4 \pm 0.22$ in the comparison group. This means that prolonged rupture to delivery interval at the gestational age of 34-36 weeks may be due to the woman's body biological unpreparedness for the labor. Besides, according to research projects by Russian scientists,

\section{References}

1. Aleyev I. A. Prezhdevremennyy razryv plodnykh obolochek. Informatsionnoye pismo / pod red. V. E. Radzinskogo, I. M. Ordiyants. - M.: Mediabyuro Status Praesens, 2011: 20p.

2. Autleva S. R. Otsenka effektivnosti preinduktsii prezhdevremennykh rodov pri prezhdevremennom razryve plodnykh obolochek. Avtoref. dis. ... kand. med. nauk. - Volgograd, 2013: 24p.

3. Bolotskikh V. M. Opyt primeneniya mifepristona pri prezhdevremennom izlitii okoloplodnykh vod. Rossiyskiy vestnik akushera-ginekologa. 2010;(3):32-35.

4. Kira E. F., Semenova K. E., Markaryan A. M. Rol' phmetrii v diagnostike vaginalnykh infektsiy. Ginekologiya. 2014;(2):9-13.

5. Kulikov I. A. Osobennosti patologii sheyki matki vo vremya beremennosti. Avtoref. dis. ... kand. med. nauk. Moskva, 2011: 24p.

6. Novikova V. A., Penzhoyan G. A., Rybalka E. V., Autleva S. R. et al. Rol' infektsii v prezhdevremennom razryve plodnykh obolochek. Rossiyskiy vestnik akushera-ginekologa. 2012;(6):35-39.

7. Novikova V. A. Sovremennyye vozmozhnosti preinduktsii prezhdevremennykh rodov v sroke beremennosti 34-36 nedel pri prezhdevremennom razryve plodnykh obolochek. Lechashchiy vrach. 2014;(4):84-89.

8. Pavlov A. V. Osobennosti funktsionalnoy aktivnosti perifericheskikh neytrofilov i produtsiruyemykh imi media- the major specific feature about premature rupture of membranes making it different from risk of abortion, e.g. at the age of 22-33 weeks, is the absence of TLR9 and MMP9 mRNA expression by peripheral neutrophils and changes in the calprotectin levels. PROM at this age is accompanied by increased production of proinflammatory cytokines (IL-1 $\beta$ ) by neutrophils, which testifies to their activation. Increased intracellular production of IL-1 $\beta$ may be due to urogenital infections that are considered triggers of inflammation [8].

The duration of the rupture to delivery interval (RTDI) in the main group was 109.1 \pm 12.63 hours (min $17-\max 248 \mathrm{hrs})(\mathrm{p}<0.001)$ and in the comparison group it was $5.24 \pm 0.06$ hours ( 1 to $12 \mathrm{hrs}$ ). Mention to be made here that 33 (33\%) women with PROM did not seek medical attention due to the absence of regular labor activity, and the duration of RTDI, which was calculated hypothetically, was above 24 hours.

Conclusions. The major risk factor found to be behind prolonged RTDI in case of PROM at 34-36 weeks' gestation are bleeding / spotting from the genital tract in different trimesters of pregnancy (84\%, $p<0.001)$, cervical ectopia $(66 \%, p<0.001)$, infection $(25 \%)$, hydramnion $(20 \%, p<0.01)$, preterm delivery, and PROM in past medical history $(23 \%, p<0.01)$, as well as the woman's age of over 35 (18\%, $\mathrm{p}<0.01)$; Enterococcus faecialis and Escherichia coli in the cervical canal discharge $(p<0.05)$.

In women with cervical ectopia at a pregnancy term of under 21 weeks, shortened cervix below $25 \mathrm{~mm}$, as well as dilatation of the cervical canal to $1.0 \mathrm{~cm}$ in diameter, may provide conditions for infection of the lower pole of fetal bladder and premature rupture of membranes. Women with PROM at the gestational age of $35.6 \pm 1.14$ weeks may have RTDI of 109.1 12.63 ( $\min 17-\max 248$ ) hours preceding spontaneous labor onset.

torov pri nevynashivanii beremennosti pozdnikh srokov. Avtoref. dis. ... kand. med. nauk. - Ivanovo, 2011: 24p.

9. Serov V. N., Sukhikh G. T. Klinicheskiye rekomendatsii. Akusherstvo i ginekologiya. - M.: GOETAR-Media, 2014: $1024 p$.

10. Tirskaya Yu. I., Rudakova E.B., Shakina I.A., Tsygankova O.Yu. Rol tservitsitov v akushersko-ginekologicheskoy patologii. Lechashchiy vrach. 2009;(10):63-66.

11. Unanyan A. L., Kossovich Yu. M. Khronicheskiy tservitsit: osobennosti etiologii, patogeneza, diagnostiki i lecheniya. Rossiyskiy vestnik akushera-ginekologa. 2012;(6):40-45.

12. Adeniji A. O., Atanda O. O. A. Interventions and neonatal outcomes in patients with premature rupture of fetal membranes at and beyond 34 weeks gestational age at a tertiary health facility in Nigeria. British Journal of Medicine \& Medical Research. 2013;3(4):1388-1397.

13. Agrawala V., Hirscha E. Intrauterine infection and preterm labor. Semin Fetal Neonatal Med. 2012;17(1):12-19.

14. Alabama Perinatal Excellence Collaborative (APEC). Guidelines: Premature rupture of membranes. Protocol 9, version 3;2013: 7p.

15. Buchanan S. L., Crowther C. A., Levett K. M. et al. Planned early birth versus expectant management for women with preterm prelabour rupture of membranes prior to 37 weeks' gestation for improving pregnancy outcome. Cochrane Database Syst Rev. 2010;17(3):CD004735. doi:10.1002/14651858.CD004735.pub3. 
16. Carroll S., Knowles S. Clinical practice guideline: preterm prelabour rupture of the membranes / Institute of Obstetricians and Gynaecologists, Royal College of Physicians of Ireland and Directorate of Strategy and Clinical Care, Health Service Executive. 2013. Version 1.0. Guideline № 24:19.

17. Mohr T. Premature rupture of the membranes. Gynekol Endokrinol. 2009;5(1):28-36.
18. Romero R., Espinoza J., Goncalves L. F., Kusanovic J. P. Friel L., Hassan S. The role of inflammation and infection in preterm birth. Semin Reprod Med. 2007;25:21-39.

19. Romero R., Chaiworapongsa T., Savasan Z. A. et al. Clinical chorioamnionitis is characterized by changes in the expression of the alarmin HMGB1 and one of its receptors, sRAGE. J Matern Fetal Neonatal Med. 2012;25:558-567.

About authors:

Shakhbazova Violetta Anatolievna, Postgraduate, doctor Department for Obstetrics, Gynecology, and Perinatology for Professional In-Service Training and Refreshment Courses, Kuban State Medical University, Russia; tel.: +78612220114; e-mail: sor.violetta2010@yandex.ru

Autleva Susanna Ruslanovna, MD, Obstetrician-Gynecologist; Gynecologist and Fertility Expert, Kuban Medical Center, Russia; tel.: +78612521455

\title{
INVOKED VISUAL POTENTIALS IN THE STUDY OF THE VISUAL ANALYZER IN PATIENTS WITH DIFFUSE SCLEROSIS
}

\author{
Karpov S. M., Padgigova Z. B., Karpov A. S., Vishlova I. A.
}

Stavropol State Medical University, Stavropol, Russian Federation

\section{ВЫЗВАННЫЕ ЗРИТЕАЬНЫЕ ПОТЕНЦИААЫ В ИССАЕАОВАНИИ ЗРИТЕАЬНОГО АНАЛИЗАТОРА У БОАЬНЫХ С РАССЕЯННЫМ СКАЕРОЗОМ}

\author{
С. М. Карпов, 3. Б. Пажигова, А. С. Карпов, И. А. Вышлова \\ Ставропольский госуАарственный меАицинский университет, \\ Ставрополь, Российская ФеАерация
}

The Purpose of the study was to examine the neurophysiological characteristics of the visual analyzer in patients with multiple sclerosis (MS) to optimize early diagnosis of the disease.

The study involved 79 patients ( 57 women and 22 men), mean age was $34.31 \pm 4.7$ years with a confirmed diagnosis of multiple sclerosis.

The results of neurophysiological studies have shown that in MS the demyelination processes in the structures of the visual analyzer in a variety of light spectrum not occur equally. The most pronounced significant $(p<0.01)$ deviations in the parameters invoked visual potentials secondary progressive multiple sclerosis on the black and white checkerboard pattern was observed in patients with primary progressive multiple sclerosis and clinical form of the changeover point. The indicator of the latent period of the wave R100 was increased sharply and significantly $(p<0.001)$ differed from the control group. Amplitude analysis made it possible to note a significant decrease in the strength of the response wave N75-N100 black-and-white stimulus in all clinical groups, making up on average of $3,3 \mathrm{mV}$ (control of $8.5 \mu \mathrm{v}$ ). The indicator of the latent period, the red-yellow chess pattern wave R100 was significantly increased and significantly $(p<0.001)$ differed from the control group. Similar changes were observed in green-and-black checkerboard pattern. When examined 25 patients with MS revealed increased levels of IgG antibodies to myelin basic protein.

The changes lead to a sharp decrease in the response of the cortical reaction. The use of color pattern will largely contribute to improving the early diagnosis of multiple sclerosis.

Key words: invoked potentials, visual analyzer, multiple sclerosis

Изучены нейрофизиологические особенности зрительного анализатора у 79 больных с рассеянным склерозом для оптимизации ранней диагностики. Женщин было 57 , мужчин - 22, средний возраст больных 34,3 44,7 лет.

Результаты нейрофизиологического исследования показали, что при РС процессы демиелинизации в структурах зрительного анализатора на разный световой спектр протекают неодинаково. Наиболее выраженные достоверные $(p<0,01)$ отклонения по параметрам ВЗП на черно-белый шахматный паттерн наблюдались у больных с ВПРС и ППРС клинической формой. Показатель ла- 